\title{
Colloquy
}

\section{GESTURES OF CARE AND RECOGNITION: An Introduction}

\author{
LAUREN CUBELLIS \\ Washington University in St. Louis \\ (iD) https://orcid.org/0000-0002-8355-7490
}

In this collection of essays, we propose an opening for anthropological conversations about care. Care has emerged increasingly as an object of study, one variously marked as morally and economically intertwined (Zelizer 2005; Kleinman 2010); constituted by politics, process, and improvisation (Mol 2008; Martin, Myers, and Viseu 2015); and technologically mediated and insidiously violent (Biehl 2015; Garcia 2015). Into this discussion we offer an intervention that considers the affective encounters (Mazzarella 2017) from which unexpected conceptions of caring emerge, and ask what ethnography might offer by way of a caring gesture. The collection derives from a Wenner-Gren-supported workshop on theoretical and ethnographic explorations of care, and what our group found, more than anything else, was that our encounters with care were embedded in anxiety, loss, and absence. To think about the way absence becomes its own marker of care, we began thinking with the concept of trace - the remnant by which a former presence is indexed, the absence that remains, and how this absent presence is recognized.

Our encounter with care as an experience of anxiety or loss does not, in many ways, seem all that surprising. Etymologically, at the root of care lies the experience of sorrow, anxiety, and grief. The Old English accounts of caru tether it to a

CULTURAL ANTHROPOLOGY, Vol. 35, Issue 1, pp. 1-5, ISSN 0886-7356, online ISSN 1548-1360. (C) American Anthropological Association 2020. Cultural Anthropology journal content published since 2014 is freely available to download, save, reproduce, and transmit for noncommercial, scholarly, and educational purposes. Reproduction and transmission of journal content for the above purposes should credit the author and original source. Use, reproduction, or distribution of journal content for commercial purposes requires additional permissions from the American Anthropological Association; please contactpermissions@americananthro.org.DOI:10.14506/ca35.1.01 
"primary sense of inward grief" and the "concern [or] anxiety caused by apprehensions of evil or the weight of many burdens" (Fine 2007; Puig de la Bellacasa 2012; Harper n.d.). Gestures of care can both direct attention toward such anxieties and perform said attentions without any intention of effect, rendering them, at worst, empty gestures (Žižek 1997; Hoffman 2016). We intend these essays as openings toward the former, as careful retellings of absent fields that recognize something about the human experience. We offer minor gestures (Manning 2016): Existing inescapably in relation to the major chord - the structural tendencies that disseminate predetermined values - but never dependent on or defined by it, the work of the minor allows for the unexpected to emerge amid seemingly structured contexts. Uniquely configured but resonantly attuned, it is "the gestural force that opens experience to its potential variation” (Manning 2016, 1). Holding space for minor gestures means writing in such a way that traces are held gently and allowed to evolve. By endeavoring toward an open-ended recognition of care, or of what makes a situation care-full, these essays expand care without delimiting it, without demanding the coordinates of that which is absent be concretely known.

Recognition diverges here from accounts that focus on witnessing (Marcus 2005), multicultural politics (C. Taylor 1994), or cognitive capacity (Ricoeur 2005). Rather, recognition is the acknowledgment that in writing ethnographically we bring into being a representation for which we assume responsibility, and which will momentarily presence something or someone in spite of their absence. Janelle S. Taylor $(2008,326)$ writes that “'recognition' is inseparable from 'caring,' and both can be understood as not just the interior emotional or intellectual states of individuals, but as practices, particular forms of activity, at once social, representational, and very concretely material." The authors in this collection strive to practice ethnographic representation that limits the determinism of our own recognition, holding open the ambivalence of caring as it is experienced by our interlocutors, and foregrounding the resolute uncertainty of such a dynamic. The work of representation here is carefully attuned — meaning with a certain willingness to hold anxiety and worry affectively in writing - to the impossibility of the task. Recognition becomes a labor that is intensely present, and that is experienced affectively, even as past and future threaten to shift and distort that image. The traces we recognize through ethnographic practice will always fail to capture the totality of that which is absent, and yet we find that in trying to do so we take up practices of caring.

In conjuring the trace, we highlight the dynamic potential of absence and presence that constitute the affective interrelationship fundamental to care. 
“Trace," Walter Benjamin (1999, 447) writes, "is appearance of a nearness, however far removed the thing that left it behind may be." The trace is distant, even as it appears near. It has a material quality, even in its absence. It is, theoretically, a static entity, but one that becomes dynamically complex as soon as it is engaged as referent. Following Jacques Derrida (1976), the trace signals an inaccessible source; we search for it in our fieldnotes and through our writing, but the trace remains the "mark of the absence of a presence, an always-already absent present" (Spivak 1976, xvii). When we write ethnographically, we pursue this absence, and when we read ethnographic work, we often encounter a feeling of nearness despite our infinite remove from the origin of the work itself. Extending this theoretical endeavor, the essays that follow allow the negotiation of the absent/present trace to become affective, a sort of raw material or nodal point around which myriad forms might refract. This constitutes the means by which it becomes illustrative of care as we have described it: the ineffable trace, persistent in its absence, renders itself multiply meaningful in the forms of recognition we afford it.

Traces are not fixed. The essays collected here examine contexts of care in which traces surge and recede, in which absence and presence are fragile and reciprocally bound. Whether as an "impossible science" of recognition (Stevenson 2020) or a transient site of political alliance (Lancione 2020), the challenge of representing past encounters that register as care-full infuses these essays. This is in some cases mediated by an attention to the unfolding of language and listening (Cubellis 2020), or the imposition of care that marks one as dangerous so as to be deserving (MacLeish 2020), or the possibility of grief as an experience that resists closure (Wool 2020). Most important, these essays also ask, both explicitly and through their attempts at challenging representation: What are the traces that we carry - what are the absences that anthropology co-creates, and how do the accounts we produce of recognition through writing form part of that process?

Moving anthropological conversations beyond the assessment of good or bad care, and beyond the acknowledgment of the concept's ambivalence, this collection provokes consideration of care as a discomfort that insists, as an affective state that does not resolve, and as one that resists finalizability. The trace has a palpable force by which it makes itself felt, assuming a nearness that threatens to overwhelm, at the same time that it recedes and remains inaccessible and indeterminate. By writing in its direction, we offer a minor gesture. By attending to that which has impressed itself, which stays with us, even if we cannot access whence it came, we gather traces, and we offer these representations as imperfect but propitious gestures of care. 


\begin{abstract}
This collection of essays offers an exploration of care as a gesture of recognition. As both object of inquiry and ethnographic representation, care is examined as the work of discerning and representing traces. The introduction and subsequent essays grapple with the work of writing about absent others, and how the anthropological endeavor might itself be considered a form of care. [care; representation; trace]
\end{abstract}

\title{
NOTES
}

Acknowledgments The essays in this Colloquy were made possible by a Wenner-Gren Foundation Workshop Grant to further theoretical and ethnographic explorations of care. We offer special thanks to our colleagues João Biehl, Paul Brodwin, Cristiana Giordano, Kim Hopper, Rebecca Lester, Joerg Niewoehner, and Jeannette Pols for their participation in the workshop, and for their generous thoughts and provocations. The essays in this Colloquy are a reflection of this collective endeavor.

\section{REFERENCES}

Benjamin, Walter

1999 The Arcades Project. Translated by Howard Eiland and Kevin McLaughlin. Cambridge, Mass.: Harvard University Press.

Biehl, João

2015 “Care and Disregard.” In A Companion to Moral Anthropology, edited by Didier Fassin, 242-63. New York: Wiley-Blackwell.

Cubellis, Lauren

2020 "Sympathetic Care." Cultural Anthropology 35, no. 1: 14-22. https://doi. org/10.14506/ca35.1.03.

Derrida, Jacques

1976 Of Grammatology. Translated by Gayatri Chakravorty Spivak. Baltimore, Md.: Johns Hopkins University Press.

Fine, Michael D.

2007 A Caring Society? Care and the Dilemmas of Human Service in the 21st Century. New York: Palgrave Macmillan.

Garcia, Angela

2015 "Serenity: Violence, Inequality, and Recovery on the Edge of Mexico City." Medical

Harper, Douglas

$$
\text { Anthropology Quarterly 29, no. 4: 455-72. https://doi.org/10.1111/maq.12208. }
$$

n.d. "Care." Online Etymology Dictionary. Accessed December 5, 2019. https://www.

Hoffman, Danny etymonline.com/word/care.

2016 "A Crouching Village: Ebola and the Empty Gestures of Quarantine in Monrovia." Kleinman, Arthur City and Society 28, no. 2: 246-64. https://doi.org/10.1111/ciso.12083.

2010 "Caregiving: The Divided Meaning of Being Human and the Divided Self of the Caregiver." In Rethinking the Human, edited by J. Michelle Molina and Donald K.

Lancione, Michele Swearer, 16-27. Cambridge, Mass.: Harvard University Press.

2020 “Underground Inscriptions." Cultural Anthropology 35, no. 1: 31-39. https://doi. MacLeish, Ken org/10.14506/ca35.1.05.

2020 "Care and the Nonhuman Politics of Veteran Drunk Driving." Cultural Anthropology 35, no. 1: 23-30. https://doi.org/10.14506/ca35.1.04. 
Manning, Erin

2016 The Minor Gesture. Durham, N.C.: Duke University Press.

Marcus, George E.

2005 "The Anthropologist as Witness in Contemporary Regimes of Intervention." Cultural Politics 1, no. 1: 31-49. https://muse.jhu.edu/article/584151.

Martin, Aryn, Natasha Myers, and Ana Viseu

2015 "The Politics of Care in Technoscience." Social Studies of Science 45, no. 5: 625-41. https://doi.org/10.1177\%2F0306312715602073.

Mazzarella, William

2017 The Mana of Mass Society. Chicago: University of Chicago Press.

Mol, Annemarie

2008 The Logic of Care: Health and the Problem of Patient Choice. New York: Routledge.

Puig de la Bellacasa, María

2012 “Nothing comes without its world': Thinking with Care.” Sociological Review 60, no. 2: 197-216. https://doi.org/10.1111\%2Fj.1467-954X.2012.02070.x.

Ricoeur, Paul

2005 The Course of Recognition. Translated by David Pellauer. Cambridge, Mass.: Harvard University Press.

Spivak, Gayatri Chakravorty

1976 Translator's preface to OfGrammatology, by Jacques Derrida, ix-lxxxviii. Translated by Gayatri Chakravorty Spivak. Baltimore, Md.: Johns Hopkins University Press.

Stevenson, Lisa

2020 "Looking Away." Cultural Anthropology 35, no. 1: 6-13. https://doi.org/10.14506/ ca35.1.02.

Taylor, Charles

1994 "The Politics of Recognition." In Multiculturalism: Examining the Politics of Recognition, edited by Amy Gutmann, 25-73. Princeton, N.J.: Princeton University Press.

Taylor, Janelle S.

2008 “On Recognition, Caring, and Dementia." Medical Anthropology Quarterly 22, no. 4: 313-35. https://doi.org/10.1111/j.1548-1387.2008.00036.x.

Wool, Zoë

2020 "Mourning, Affect, Sociality: On the Possibilities of Open Grief." Cultural Anthropology 35, no. 1: 40-47. https://doi.org/10.14506/ca35.1.06.

Zelizer, Viviana A.

2005 The Purchase of Intimacy. Princeton, N.J.: Princeton University Press.

Žižek, Slavoj

1997 The Plague of Fantasies. New York: Verso. 